\title{
ProQuest acquires WebFeat
}

\author{
Merger with Serials Solutions is planned
}

Ann Arbor, Mich., February 14, 2008 - ProQuest, a Cambridge Information Group company, has acquired WebFeat, acclaimed pioneer of federated search, a technology that enables simultaneous search of all an organization's databases, dramatically increasing research productivity. ProQuest plans to merge WebFeat with Serials Solutions, its Seattle-based business unit and developer of e-resource access and management tools for libraries.

"WebFeat is an exceptional fit with Serials Solutions and within ProQuest as a whole", said Marty Kahn, ProQuest CEO. "It brings significant technological expertise that will be furthered enhanced when combined with Serials Solutions' technology. Just as important is WebFeat's commitment to delivery of superior service to libraries. It's a perfect match with our organization".

Under the leadership of Serials Solutions' general manager, Jane Burke, the strengths of WebFeat's and Serials Solutions' federated search platforms will be combined to create a single, market-leading solution. The new platform will debut in early 2009 , providing libraries with more power and efficiency in accessing their data pools. The current search platforms from both Serials Solutions and WebFeat will continue to be supported as this development proceeds.

"With more and more e-resources in collections, librarians are looking hard at the tools that will deliver the greatest level of 'discovery' and federated search is one of the most important", said Ms. Burke. "Merging Serials Solutions and WebFeat will combine the best of this technology and create a superior tool for access".

Founded by information industry veteran Todd Miller, WebFeat introduced the first federated search technology in 1998 and has continued as a market leader, serving more than 16,500 libraries, conducting more than 172 million database searches annually. Mr. Miller, who holds four patents in the field of federated search, will remain with WebFeat briefly as a consultant. Then, WebFeat employees will be aligned functionally within Serials Solutions' current organizational structure. While WebFeat staff will become part of Serials Solutions, its customer support and all development activities will continue uninterrupted.

"I'm proud to see WebFeat enter the next chapter of its history as part of a company that is committed to creating the tools that will keep libraries central to the research process", said Mr. Miller. "WebFeat and Serial Solutions have an exceptional combination of strengths and I'm certain this merger will take federated search to the next level".

\section{About ProQuest}

ProQuest provides seamless access to and navigation of more than 125 billion digital pages of the world's scholarship, delivering it to the desktop and into the workflow of serious researchers in multiple 
fields, from arts, literature and social science to science, technology and medicine. ProQuest is part of Cambridge Information Group (www.cambridgeinformationgroup.com).

ProQuest's vast content pools are available to researchers through libraries of all types and include the world's largest digital newspaper archive, periodical databases comprising the output of more than 9,000 titles and spanning more than 500 years, the pre-eminent dissertation collection, and various other scholarly collections. Users access the information through the ProQuest ${ }^{\circledR}$ and CSA Illumina ${ }^{\mathrm{TM}}$ online information systems, Chadwyck-Healey ${ }^{\mathrm{TM}}$ electronic and microform resources, UMI ${ }^{\circledR}$ microform and print reference products, eLibrary ${ }^{\circledR}$ and SIRS ${ }^{\circledR}$ educational resources, Ulrich's ${ }^{\circledR}$ Serials Analysis System, COS Scholar Universe and Serials Solutions ${ }^{\circledR}$ resource management tools. Through the expertise of business units Serials Solutions and RefWorks/COS, ProQuest provides technological tools that allow researchers and libraries to better manage and use their information resources. For more information, visit: www.proquest.com, www.proquest.co.uk and www.csa.com.

\title{
About Serials Solutions
}

Since introducing the first A-to-Z Title List in 2000, Serials Solutions has been a global leader in the library technology marketplace. Founded by a librarian for librarians, Serials Solutions helps library staff and patrons find and use electronic content. Today, with over 2,000 clients worldwide, Serials Solutions is the premier vendor of e-resource access and management services (ERAMS), providing a complete and integrated access and management solution for libraries of all sizes and types. The Serials Solutions family of services includes 360 Core, 360 Link, 360 Search, 360 MARC Updates, 360 Resource Manager and the new 360 Counter e-resource assessment service. The foundation of Serials Solutions technology is Serials Solutions KnowledgeWorks, the authoritative e-resource knowledgebase. Serials Solutions is also the exclusive source for Ulrichsweb.com and Ulrich's Serials Analysis System. Through its Software as a Service (SaaS) technology model, Serials Solutions provides fast implementation, easy customization, and outstanding value to its client libraries. Serials Solutions is a business unit of ProQuest. For more information, please visit: www.serialssolutions.com or call 1-866-SERIALS.

\begin{abstract}
About WebFeat
WebFeat $^{\circledR}$ is the developer of the WebFeat and WebFeat Express ${ }^{\mathrm{TM}}$ Search Solutions, used by more than 16,500 leading public, academic, government and Global 1,000 libraries and information centers. Its next-generation federated search and e-resource management tools are used by the US's largest public libraries, as well as a variety of statewide library systems and the nation's most prestigious research libraries. Its products include WebFeat Express federated search solution, WebFeat Enterprise Edition for multi-library networks, WebFeat Custom API and SMART ${ }^{\mathrm{TM}}$, WebFeat's usage tracker. WebFeat Menu Manager $^{\mathrm{TM}}$ and WebFeat Proxy ${ }^{\mathrm{TM}}$ provide tools for access and management of e-resource collections. The company has earned industry recognition from such leading organizations as Library Journal and the Gartner Group. Learn more about WebFeat at: www.webfeat.org.
\end{abstract}

